\title{
ERRATUM
}

\section{Racial differences in primary cytogenetic abnormalities in multiple myeloma: a multi-center study}

AJ Greenberg, S Philip, A Paner, S Velinova, A Badros, R Catchatourian, R Ketterling, RA Kyle, S Kumar, CM Vachon and SV Rajkumar

Blood Cancer Journal (2015) 5, e279; doi:10.1038/bcj.2015.8; published online 13 February 2015

Correction to: Blood Cancer Journal (2015) 4, e271; doi:10.1038/bcj. 2014.91; published online 2 January 2015

Since publication, the publishers have identified that this article was incorrectly placed in volume 4 . The article belongs in volume 5 .
The publishers would like to apologise for any inconvenience caused.

The article has been rectified and now carries the correct information. 